\section{JTS}

http://penerbit.uthm.edu.my/ojs/index.php/jts ISSN : 2229-8940 e-ISSN : 2600-7940
Journal of Techno

Social

\title{
Low Carbon Lifestyle among Household
}

\section{Amalan Rendah Karbon dalam Kalangan Isi Rumah}

\author{
Hanifah Mahat ${ }^{1 *}$, Doreen Anak Pasang ${ }^{2}$, Mohmadisa Hashim ${ }^{3}$, \\ Yazid Saleh $^{4}$, Nasir Nayan ${ }^{5}$
}

1, 2, 3, 4,5Jabatan Geografi \& Alam Sekitar, Fakulti Sains Kemanusiaan,

Universiti Pendidikan Sultan Idris, Tanjong Malim, 35900, MALAYSIA

*Corresponding Author

DOI: https://doi.org/10.30880/jst.2018.11.01.004

Received 00 Month 2000; Accepted 01 Month 2000; Available online 30th June 2019

\begin{abstract}
In order to address the issue of climate change and global warming, scientists and policy makers all around the world suggest that a drastic reduction in the consumption of electricity to be carried out. Low carbon practices undertaken by households, such as saving electricity is a good effort for the survival of future generations. This is because households are seen as an important target group for energy conservation. Thus, this study aimed to see the difference of income with the usage of electrical appliances and relationship between the usage of elctrical appliances and household energy saving practioces. Methodology of this study was completely based on questionnaire involving 400 respondents representing households and were selected using random sampling techniques. The results of ANOVA test shows there is a significant difference between income varible with the usage of electrical apliances which income variable $(F=10.311$ with $p<0.05)$. The study also found that the use of electrical appliances by households has a negative and weak relationship with household energy saving practices. The findings from this study clearly show that through the difference in income, energy usage pattern of electrical appliances by households also has changed. Thus, if the awareness of saving electricity is not practiced among householders, global warming and climate change will be a long-term issue that will concern the various parties.
\end{abstract}

Keywords: low carbon practices, households, electric appliances used, income, energy saving behaviour 


\begin{abstract}
Abstrak: Dalam usaha untuk menangani isu perubahan iklim dan pemanasan global, para saintis dan pengubal dasar seluruh dunia mencadangkan agar pengurangan secara drastik dalam penggunaan tenaga elektrik harus dilaksanakan. Amalan rendah karbon yang dilakukan oleh isi rumah seperti menjimatkan tenaga elektrik adalah satu usaha yang baik demi kelangsungan hidup generasi akan datang. Justeru, kajian ini bertujuan untuk meneliti pendapatan isi rumah dengan penggunaan barangan elektrik dan hubungan antara penggunaan barangan elektrik dan amalan penjimatan tenaga isi rumah. Kaedah kajian adalah sepenuhnya berasaskan soal selidik yang melibatkan 400 responden yang mewakili isi rumah dan telah dipilih dengan menggunakan teknik persampelan rawak mudah. Hasil kajian daripada ujian ANOVA menunjukkan terdapat perbezaan yang signifikan antara pemboleh ubah pendapatan dengan penggunaan barangan elektrik iaitu pemboleh ubah pendapatan $(\mathrm{F}=10.311$ dengan $\mathrm{p}<0.05$ ). Kajian juga mendapati bahawa penggunaan barangan elektrik oleh isi rumah mempunyai hubungan signifikan yang negatif dan lemah dengan amalan penjimatan tenaga elektrik. Dapatan ini jelas menunjukkan bahawa melalui perbezaan dalam pendapatan menyebabkan corak penggunaan barangan elektrik oleh isi rumah turut berbeza. Justeru, jika kesedaran terhadap penjimatan elektrik tidak diamalkan dalam kalangan isi rumah, pemanasan global dan perubahan iklim akan menjadi isu jangka panjang yang akan membimbangkan pelbagai pihak.
\end{abstract}

Kata Kunci: amalan rendah karbon, isi rumah, penggunaan barangan elektrik, amalan penjimatan tenaga elektrik

\title{
1. Pengenalan
}

Cara hidup rendah karbon adalah satu aktiviti yang memberi sokongan penuh kepada alam sekitar, mengubah setiap butiran cara hidup melalui penjimatan tenaga dan pemulihan bagi mengurangkan pelepasan karbon, terutamanya karbon dioksida, yang mana ia menunjukkan satu gaya hidup rendah tenaga, rendah penggunaan dan rendah kos (Gaidajis, Angelakoglou \& Aktsohlou, 2010; Mulugetta \& Urban, 2010). Dalam konteks ini, proses pembangunan perlu menitikberatkan konsep kelestarian supaya kehidupan yang sejahtera dan harmoni antara alam sekitar dan manusia dapat terjamin (Zainal, Kamarudin, \& Azlizan, 2014). Bagi mencapai sebuah masyarakat yang rendah karbon, sesebuah bandar atau wilayah perlu rendah karbon di semua aspek termasuklah ekonomi, kehidupan seharian, politik dan budaya. Ini bermakna, komuniti rendah karbon adalah ringkasan bagi sebuah bandar yang rendah karbon (Jenni, Poikela, Lehtinen, Keiski, Pongracz, 2014; Yuan, Zhou \& Zhou, 2011). Manusia sememangnya sedar bahawa punca kepada isu iklim adalah disebabkan oleh peningkatan karbon yang berlebihan di ruangan atmosfera. Dengan memperkenalkan gaya hidup yang rendah karbon boleh meningkatkan lagi tanggungjawab masyarakat dan memupuk kesedaran mengenai penjimatan tenaga yang lebih cekap (Broer, 2012). Selain daripada dapat menjimatkan sumber alam, mengurangkan pelepasan gas rumah hijau dan melindungi alam sekitar dan seterusnya membina sebuah kehidupan yang mampan (Pang, Chen, Zhang, \& Li, 2016; Rafia Afroz, Muhammad Mehedi, Rulia Akhtar \& Jarita, 2013). Bagi mengurangkan pelepasan karbon doksida (CO2) tetapi bergerak serentak dalam mengekalkan pertumbuhan ekonomi, negara seperti Jepun dan Amerika Syarikat kini telah mempunyai target sendiri terhadap jumlah pelepasan karbon ke ruangan atmosfera. Negara-negara ini juga telah mencari alternatif baru untuk perkembangan ekonomi dalam pembangunan rendah karbon (Khandakar, 2016; Simson, 2012).

Dalam konteks Malaysia, masih berlaku secara berleluasa rakyat di negara ini suka membazir sumber utama dengan tingkah laku menggunakan tenaga elektrik secara berlebihan misalnya, sengaja tidak menutup suis lampu, kipas, suis komputer dan sebagainya walaupun tidak menggunakan kemudahan tersebut (Fauziah, 2011). Kesannya penggunaan sumber tenaga dalam aspek persekitaran adalah pencemaran. Laporan UNDP meletakkan Malaysia dalam kedudukan ke-62 daripada 70 buah negara yang menghasilkan pelepasan gas karbon dioksida (CO2) tertinggi di dunia bagi tahun 2011. Dalam data World Bank (2015), purata pelepasan karbon dunia pada tahun 2010 dianggarkan sebanyak 4.6 metrik tan per kapita dan Malaysia melepaskan sebanyak 7.7 metrik tan per kapita pada tahun 2010. Data World Bank (2015) turut melaporkan kadar penghasilan gas CO2 di Malaysia didapati meningkat dari 3.1 metrik tan per kapita (tCO2) pada 1990 kepada 5.4 metrik tan per kapita pada tahun 2005 dan meningkat lagi kepada 7.7 tCO2 pada tahun 2010. Menurut Perangkaan Jabatan Statistik (2009), jumlah bilangan penduduk Malaysia pada 2008 ialah seramai 27.73 juta. Oleh itu, dengan menggunakan kadar pelepasan karbon dioksida per kapita sebanyak 7.5 tCO2 dianggarkan penduduk Malaysia menghasilkan kira-kira 208 juta tCO2 pada 2008 (UNDP, 2007). Kajian daripada Penilaian Kitar Hayat (Life Cycle Assessment - LCA) membuktikan bahawa kadar pelepasan karbon tertinggi bagi peralatan elektrik dan elektronik adalah semasa penggunaannya. Kerajaan Malaysia melalui Kementerian Tenaga, Teknologi Hijau dan Air (KeTTHA), memainkan peranan penting dalam menggubal dan melaksanakan dasar berkaitan dengan penjimatan tenaga. Di dalam Rancangan Malaysia Ke-10 (RMK-10) iaitu dari tahun 2011 hingga 2015, Pelan Induk Kecekepan Tenaga Nasional (NEEM) telah dibangunkan bagi memberi panduan dan halatuju penggunaan tenaga dengan cekap, khususnya penggunaan barangan elektrik. Namun amalan penjimatan tenaga adakah mencapai sasaran pihak kerajaan. Justeru fokus kajian adalah untuk meneliti sejauhmana amalan rendah karbon isi rumah. Bersandarkan tujuan ini, objektif kajian yang akan dibincangkan dalam artikel ini adalah (i) meneliti tahap penggunaan barangan 
elektrik isi rumah, (ii) mengenalpasti perbezaan pendapatan dengan penggunaan barangan elektrik dan (iii) meneliti hubungan antara pemboleh ubah penggunaan barangan elektrik dan amalan penjimatan tenaga elektrik isi rumah.

\subsection{Faktor Penentu dalam Penggunaan Barangan Elektrik}

Perubahan iklim dan pemanasan global merupakan satu isu alam sekitar yang terpaksa dihadapi oleh masyarakat secara global pada masa kini dan jika langkah yang intensif tidak diambil dari peringkat awal untuk mengurangkan pelepasan gas rumah hijau, maka dalam beberapa tahun yang akan datang, keadaan alam sekitar yang merupakan sebuah tempat bergantung oleh kesemua hidupan bumi akan menjadi bertambah buruk (Jamilah, Shuhaida \& Nurzali, 2017; Pachauri et al, 2014). Pelepasan gas rumah hijau dapat dikurangkan sama ada mengurangkan skala penggunaan tenaga dan sumber iaitu melalui peningkatan terhadap kecekapan guna tenaga elektrik atau mengurangkan penggunaan tenaga atau memperkenalkan teknologi baharu untuk mengurangkan intensiti tenaga daripada gas rumah hijau dan sumber pula digunakan dalam pengeluaran (Andersson, 2016).

Pendapatan, saiz isi rumah, saiz tempat kediaman, penggunaan barangan elektrik dan cuaca dilihat sebagai faktorfaktor yang mempengaruhi tingkah laku dalam penjimatan tenaga elektrik di sesebuah isi rumah (Parameshwari, 2016). Kajian McClaren, (2015); Ahmad Faisal, Mohd Bakri dan Siti Nur Awanis, Rusamah, (2015) membincangkan bahawa sesebuah isi rumah yang berpendapatan tinggi cenderung untuk menggunakan barangan elektrik dengan tidak cermat dan mempunyai kesedaran terhadap label "ENERGY STAR". Namun begitu, masih berlaku pembaziran yang dalam kalangan isi rumah. Kajian daripada Lundgren dan Kjellstrom (2013) menyatakan bahawa penggunaan pendingin hawa tinggi disebabkan berlaku peningkatan dalam pendapatan dan ia turut menjadi satu keperluan untuk melindungi isi rumah daripada pendedahan haba panas yang tinggi ekoran daripada perubahan iklim dunia.

Di dalam kajian yang dijalankan oleh Jones, Fuertes, dan Lomas (2015) menyatakan bahawa terdapat 62 faktor yang memberikan kesan terhadap penggunaan barangan elektrik iaitu 13 faktor daripada sosioekonomi, 12 faktor tempat kediaman dan 37 faktor peralatan. Dalam 62 faktor tersebut, empat daripada faktor sosioekonomi, tujuh daripada faktor tempat kediaman dan sembilan daripada faktor peralatan didapati mempunyai kesan positif yang jelas terhadap penggunaan barangan elektrik. Dalam kajian Wu, Liu, dan Tang, (2012) berfokus terhadap penggunaan barangan elektrik isi rumah dan pelepasan gas karbon dioksida di bandar Lijian, China dan hasil kajian mendapati bahawa saiz keluarga, pendapatan, dan tahap pendidikan merupakan faktor utama yang mempengaruhi pelepasan gas karbon dioksida.

Aspek demografi tidak ketinggalan dalam mempengaruhi penggunaan barangan elektrik oleh isi rumah. Dalam kajian yang dijalankan oleh Zhang, (2013) mendapati bahawa faktor demografi terutamanya saiz isi rumah memberikan pengaruh yang besar terhadap penggunaan tenaga. Ini bermakna, isi rumah yang mempunyai sedikit bilangan ahli cenderung untuk menggunakan lebih tenaga per kapita berbanding dengan isi rumah yang lebih besar. Dalam kajian Zhang, (2013) turut menjelaskan bahawa faktor usia turut mempengaruhi penggunaan tenaga elektrik sejak penggunaan tenaga elektrik cenderung untuk mengubah jangka hayat warga tua. Kajian ini disokong oleh Najmi dan Keramati, (2014) yang mendapati bahawa bilangan ahli keluarga adalah bergantung kepada generasi dimana semakin meningkat usia ahli keluarga, semakin banyak penggunaan barangan elektrik yang digunakan. Dalam kajian Bhattacharjee, Reichard, McCoy, Pearce, dan Beliveau, (2014) yang menggunakan model The Core Fishbond membuktikan bahawa komponen demografi mempunyai pengaruh yang besar dalam mengawal elemen lain yang berkaitan dengannya seperti kitaran kekeluargaan, struktur kekeluargaan dan jenis pekerjaan. Manakala elemen kewangan dan tahap pendidikan adalah unsur yang penting kerana dua unsur ini muncul dalam bilangan yang maksimum pada model analisis tulang ikan yang digunakan oleh penyelidik-penyelidik. Selain daripada faktor pendapatan dan demografi, saiz tempat kediaman juga menjadi satu faktor yang mempengaruhi penggunaan tenaga elektrik.

Dalam kajian oleh Brounen, Kok dan Quigley (2012) menyatakan bahawa ciri-ciri kediaman seperti saiznya (purata saiz bagi sesebuah temapt kediaman adalah $125 \mathrm{~m} 2$ dan tempat kediaman yang lain 1345 kaki persegi serta mempunyai 5 buah bilik) mempunyai hubungan yang kuat dalam jumlah penggunaan barangan elektrik manakala berhubungan negatif dengan jangka hayat atau kediaman serta mempunyai banyak kaitan dengan kekayaan penduduk dan penyediaan lebih peralatan intensif tenaga di rumah-rumah yang moden. Analisis secara holistik corak penggunaan elektrik kawasan kediaman dan menganalisis keperluan penggunaan barangan elektrik isi rumah bagi kawasan bandar dan luar bandar di Finland dilakukan oleh Heinonen dan Junnila, (2014). Tiga jenis kawasan kediaman dikaji secara berasingan dalam kajian ini iaitu rumah jenis pangsapuri, rumah terus dan rumah banglo berkembar. Apabila saiz tempat kediaman isi rumah adalah besar contohnya rumah dua tingkat separa berkembar, maka penggunaan terhadap barangan elektrik juga turut meningkat contohnya dalam kajian yang dijalankan oleh Tso dan Guan (2014) semakin besar saiz tempat kediaman yang dimiliki oleh isi rumah, maka penggunaan pendingin hawa juga semakin meningkat untuk keperluan memberi keselesaan pengguna. Terdapat juga kajian yang menunjukkan bahawa pemilikan barangan elektrik isi rumah tidak akan mempengaruhi penggunaan barangan elektrik secara langsung, namun, bilangan dan jenis barangan elektrik yang dimiliki akan menjelaskan infrastruktur fizikal di mana penggunaan barangan elektrik akan berlaku. Dalam kata lain, semakin banyak bilangan barangan elektrik yang dimiliki, semakin besar peluang mewujudkan penggunaan elektrik (Jones \& Lomas, 2016). Namun begitu, Kleebrang, Bunditsakulchai dan Wangjiraniran (2015) memberikan pandangan yang bercanggah dengan menyatakan bahawa penggunaan dan bilangan 
barangan elektrik dalam sesebuah isi rumah adalah faktor penentu terbesar bagi keperluan tenaga elektrik untuk sektor kediaman. Kebiasaannya, penggunaan tenaga elektrik meningkat seiring dengan bilangan barangan elektrik yang dimiliki oleh isi rumah. namun begitu, bagi sebahagian jenis barangan elektrik, perkembangan teknologi telah bertambah maju yang mana membuatkan barangan elektrik tersebut lebih cekap tenaga.

\subsection{Amalan Penjimatan Tenaga Elektrik}

Isi rumah mempunyai potensi yang besar untuk mengurangkan penggunaan elektrik (Engku Siti Zaharah et al., 2013). Memahami dan mengubah tingkah laku penggunaan tenaga elektrik dalam kalangan isi rumah merupakan satu langkah yang efektif untuk meningkatkan kecekapan guna tenaga dan menggalakkan penjimatan tenaga elektrik isi rumah (Zhou \& Yang, 2016). Namun begitu, kajian daripada beberapa pengkaji seperti Fithri, Susanti, dan Bestarina, (2014); Naz Arif dan Rafia Afroz (2014); Vassileva (2012); Zareie dan Nima (2016); meyatakan bahawa isi rumah tidak mempunyai sebarang kebimbangan dalam amalan penjimatan tenaga elektrik kerana mereka mampu membayar bil elektrik.

Walau bagaimanapun, untuk mengamalkannya bagi sebahagian besar anggota masyarakat adalah sukar dilaksanakan. Hal ini adalah kerana amalan penggunaan masyarakat pada masa kini lebih mengutamakan kepada kehendak berbanding dengan keperluan (Pérez-belis, Bovea \& Simó, 2014; Siti Khatijah \& Christopher, 2016). Dalam aspek amalan penjimatan tenaga elektrik, penggunaan elektrik di kediaman berbeza dengan sektor lain seperti sektor perindustrian, yang boleh dikawal penggunaan barangan elektrik melalui peraturan atau undang-undang yang dikenakan kepada sektor lain. Ini adalah kerana isi rumah terdiri daripada individu dan agak sukar untuk memaksa mereka mematuhi peraturan berkaitan peraturan berkaitan dengan penggunaan tenaga (Hori, Kondo, Nogata, \& Ben, 2013; Nur Sumaiyyah, Gautam Lalit \& Mohd Badruddin, 2015). Untuk mengamalkan sesuatu amalan, aspek cabaran dalam melakukan amalan juga perlu dilihat. Terdapat juga isi rumah yang mahu melabur dalam langkah-langkah penjimatan tenaga elektrik tetapi kos telah menjadi penghalang utama bagi mereka (Yohanis, 2012). Pengguna seolaholah mendapat kesedaran yang besar bagi nilai dan keperluan untuk amalan kelestarian tenaga, khususnya apabila kebimbangan pelbagai pihak dalam isu pelepasan gas rumah hijau dan perubahan iklim. Namun begitu, dengan pengetahuan yang mencukupi tentang bagaimanakah amalan untuk menjimatkan tenaga dan memiliki sifat atau keinginan untuk melakukan amalan penjimatan, masih ramai pengguna gagal untuk mengambil langkah ke arah penggunaan tenaga yang cekap (Frederiks, Stenner, \& Hobman, 2015).

Sikap penangguhan juga dilihat sebagai satu cabaran dalam melakukan sesuatu amalan. Dalam kajian Lillemo (2014) melihat kecenderungan sikap penangguhan dan kesedaran mengenai alam sekeliling mempengaruhi tingkah laku pemanasan penjimatan tenaga elektrik dan didapati bahawa masyarakat lebih cenderung untuk menangguhkan perbuatan mereka dan kurang dalam penglibatan aktiviti penjimatan tenaga elektrik terutamanya mengenai pembelian yang lebih besar atau pelaburan dalam perkakas dan penebat pintu dan tingkap. Kajian juga mendapati hubungan yang positif antara kesedaran alam sekeliling dan penglibatan diri dalam aktiviti seharian seperti pengurangan suhu dalam rumah.

\section{Metodologi}

Kajian ini merupakan kajian kuantitatif dengan menggunakan kaedah pengedaran borang soal selidik bagi tujuan pengumpulan data. Kajian dilakukan di bandar Bintulu, Sarawak yang melibatkan lapan buah taman perumahan iaitu Lucky Tower, Bandar Jaya, Taman Terus, signature Park, Taman Kemena Sutera, Taman Kemena Raya, Pine Avenue dan Happy Garden. Penetapan lapan buah kawasan ini adalah bertujuan untuk meneliti penggunaan dan amalan rendah karbon yang diamalkan oleh isi rumah yang berbeza dari aspek pendapatan. Jumlah populasi di bandar Bintulu adalah seramai 189,146 orang. Responden telah dipilih menggunakan teknik persampelan rawak mudah. Berdasarkan jadual Krijie dan Morgan (1970), seramai 400 responden yang dipilih iaitu 200 bagi kawasan perumahan yang berpendapatan rendah dan 200 lagi untuk kawasan perumahan yang berpendapatan tinggi diperlukan untuk mengumpul data dalam kajian ini. Dari segi pengendalian soal selidik, pengedaran dari rumah ke rumah dilakukan dan wakil isi rumah diminta untuk mengisi soal selidik yang diedarkan.

Dalam kajian ini, dua pemboleh ubah yang terlibat iaitu penggunaan barangan elektrik dan amalan penjimatan tenaga elektrik dalam kalangan isi rumah. Ujian statistik yang digunakan adalah analisis deskriptif, ujian ANOVA dan korelasi. Ujian ANOVA digunakan bertujuan melihat perbezaan pendapatan isi rumah terhadap penggunaan barangan elektrik. Manakala analisis korelasi Pearson digunakan untuk melihat perhubungan antara penggunaan barangan elektrik dengan amalan penjimatan elektrik isi rumah.

\subsection{Instrumen kajian}

Instrumen kajian yang dijalankan bagi mendapatkan data kuantitatif ialah penggunaan soal selidik. Pembinaan item soal selidik adalah berdasarkan kajian lepas berhubung amalan hijau dan bersesuaian dengan amalan hijau yang digariskan oleh Kementerian Tenaga, Teknologi Hijau dan Air (KeTTHA). Item diukur dalam bentuk Skala Likert 5 
mata [1 - Tidak Pernah, 2 - Jarang-jarang (beberapa kali dalam sebulan), 3 - Kadang-kadang (sekali seminggu), Kerap (4-6 kali seminggu), 5 - Sangat Kerap (setiap hari)]. Di dalam konteks kajian ini, penjimatan tenaga elektrik merujuk kepada sesuatu aktiviti yang tidak melibatkan kos sebaliknya hanya memerlukan perubahan tingkah laku dalam kalangan pengguna dan ianya dicapai melalui penggunaan tenaga secara cekap, seperti memadamkan suis lampu, kipas, dan peralatan elektrik apabila tidak digunakan serta menggunakan cahaya matahari sebagai cara alternatif untuk menjimatkan penggunaan barangan elektrik. Justeru dalam pemboleh ubah amalan penjimatan tenaga elektrik isi rumah disertakan soalan seperti saya menutup suis kipas apabila hari hujan atau sejuk, saya menggunakan pendingin hawa sepanjang hari. Jadual 1 menunjukkan nilai kebolehpercayaan kajian rintis soal selidik terhadap isi rumah.

Jadual 1 - Nilai kebolehpercayaan kajian rintis soal selidik isi rumah.

\begin{tabular}{lccc}
\hline \multicolumn{1}{c}{ Pemboleh Ubah } & Bil Item & $\begin{array}{c}\text { Kajian Rintis } \\
\text { (Nilai Alpha Cronbach) }\end{array}$ & $\begin{array}{c}\text { Kajian sebenar (Nilai } \\
\text { Alpha Cronbach) }\end{array}$ \\
\hline $\begin{array}{l}\text { Amalan Penjimatan } \\
\text { Tenaga elektrik }\end{array}$ & 26 & 0.724 & 0.822 \\
\hline
\end{tabular}

\section{Hasil Kajian dan Perbincangan}

Jadual 2 menunjukkan taburan maklumat latar belakang responden di lapan buah kawasan terpilih di bandar Bintulu, Sarawak. Sejumlah 217 responden (54.3\%) adalah wakil isi rumah perempuan dan 183 responden (45.8\%) adalah lelaki. Sebahagian besar responden berumur dalam lingkungan 40 hingga 49 tahun iaitu 171 responden (42.8\%) daripada jumlah keseluruhan responden diikiuti dengan 122 responden (30.5\%) dalam lingkungan umur 30 hingga 39 tahun. Manakala, angka terendah didominasi oleh golongan umur 20 hingga 29 tahun iaitu 54 responden (13.5\%) diikuti dengan 53 responden (13.3\%) dalam lingkungan umur 50 tahun ke atas. Kajian turut melihat aspek bangsa responden dan didapati seramai 50 orang (12.5\%) bangsa Melayu diikuti dengan bangsa India 10 orang (2.5\%), bangsa Cina 185 orang $(46.3 \%)$ dan bangsa lain-lain yang terdiri 155 orang (38.8\%). Bagi status perkahwinan responden, didapati bahawa responden kebanyakkannya telah berkahwin iaitu seramai 356 orang (89.0\%) manakala yang bujang adalah seramai 37 orang $(9.3 \%)$, dan bagi responden yang duda/janda adalah seramai 7 orang $(1.8 \%)$.

\subsection{Latar belakang pekerjaan responden}

Kajian ini turut melihat aspek pekerjaan responden. Bagi sektor pekerjaan responden seramai 58 orang (14.5\%) bekerja di sektor kerajaan, 134 orang $(33.5 \%)$ bekerja di sektor swasta, seramai 142 orang (35.5\%) responden yang mempunyai pekerjaan secara persendirian dan seramai 66 orang (16.5\%) tidak bekerja atau telah pencen. Bagi anggaran pendapatan bulanan isi rumah, responden yang mempunyai pendapatan kurang daripada RM 900 adalah seramai 6 orang (1.5\%), bagi pendapatan RM 1,500 - RM 2,500 seramai 6 orang (1.5\%), bagi pendapatan RM 2,501 RM 3,500 seramai 17 orang (4.3\%), bagi pendapatan RM 3,501 - RM 4,500 seramai 13 orang (3.3\%), bagi pendapatan RM 4,501 - RM 5,500 dan bagi pendapatan yang lebih daripada RM 5,500 adalah seramai 338 orang (84.5\%). Bagi anggaran bil elektrik bulanan isi rumah, seramai 68 isi rumah (17.0\%) yang membayar RM 50 - RM 150, bil elektrik RM 151 - RM 250 dibayar oleh 43 isi rumah (10.8\%), seramai 67 isi rumah (16.8\%) membayar RM 251 - RM 350 untuk bil elektrik bulanan, seramai 138 isi rumah (34.5\%) membayar RM 351 - RM 450 untuk bil elektrik bulanan dan seramai 84 isi rumah yang membayar RM 451 - RM 550 untuk bil elektrik bulanan.

Kajian ini menggunakan 14 jenis perkakas elektrik yang telah dipilih bersama penyelia tesis, iaitu pendingin hawa, televisyen/ pembesar suara/ radio, mesin basuh, kipas meja, kipas siling, peti sejuk, lampu, cerek, ketuhar, periuk nasi elektrik, mesin air elektrik, alat pemanas mandian, komputer/ komputer riba/ notebook dan mesin cetak. Hasil dapatan (Jadual 4) menunjukkan tahap penggunaan isi rumah terhadap barangan elektrik berada pada tahap sederhana iaitu seramai 390 isi rumah $(97.5 \%)$ dengan julat skor $(41-80)$. Penggunaan barangan elektrik pada tahap rendah adalah seramai 9 buah isi rumah $(2.3 \%)$ dengan julat skor $(1-40)$ dan tahap tinggi adalah sebuah isi rumah $(0.3 \%)$ dengan julat skor $(81-120)$. Melalui dapatan ini, jelas menunjukkan bahawa penggunaan isi rumah terhadap penggunaan barangan elektrik adalah sederhana (Min=1.98, $\mathrm{SP}=0.157)$.

Ujian ANOVA dilakukan bagi mengenalpasti perbezaan pendapatan dengan penggunaan barangan elektrik (Jadual 5). Didapati wujud perbezaan yang signifikan antara pemboleh ubah pendapatan dan penggunaan barangan elektrik iaitu pemboleh ubah pendapatan $(\mathrm{F}=10.311$ dengan $\mathrm{p}<0.05)$. Dapatan kajian ini adalah selari dengan kajian Vassileva, (2012) yang menyatakan pendapatan yang rendah menunjukkan isi rumah menggunakan barangan elektrik dengan cermat kerana ingin menjimatkan kos pembayaran bil elektrik bulanan dan ini menampakkan perbezaan yang ketara apabila isi rumah yang berpendapatan tinggi cenderung untuk menggunakan barangan elektrik tanpa menghiraukan kos bil elektrik bulanan. Walau bagaimanapun, kajian daripada Kavousian, Rajagopal, dan Fischer (2013) menunjukkan percanggahan dengan menyatakan bahawa tidak terdapat perhubungan antara pendapatan dan penggunaan barangan elektrik dan mencadangkan keadaan ini berlaku kerana pendapatan mempengaruhi pemilikan barangan elektrik yang mana ia merupakan pemboleh ubah berpisah di dalam kajian yang dijalankan. 
Jadual 2 - Latar belakang pekerjaan responden.

\begin{tabular}{llcc}
\hline Latar Belakang Pekerjaan Responden & N & Peratus (\%) \\
\hline Sektor Pekerjaan & Kerajaan & 58 & 14.5 \\
& Swasta & 134 & 33.5 \\
& Persendirian & 142 & 35.5 \\
& Tidak Bekerja & 66 & 16.5 \\
& Jumlah & 400 & 100 \\
& & & 1.5 \\
Anggaran Pendapatan Isi Rumah & 1,500 ke bawah & 6 & 1.5 \\
(bulanan) (RM) & $1,501-2,000$ & 6 & 4.3 \\
& $2,001-3,500$ & 17 & 3.3 \\
& $3,501-4,500$ & 13 & 5.0 \\
& $4,501-5,500$ & 20 & 84.5 \\
& 5,501 ke atas & 338 & 100 \\
Jumlah & 400 & 17.0 \\
Anggaran Bil Elektrik (bulanan) & RM50 - RM150 & & 10.8 \\
& RM151 - RM250 & 68 & 16.8 \\
& RM251 - RM350 & 43 & 34.5 \\
& RM351 - RM450 & 67 & 21.0 \\
& RM451 - RM550 & 138 & 100 \\
\hline
\end{tabular}

Jadual 3 - Tahap penggunaan barangan elektrik.

\begin{tabular}{lccccccccc}
\hline Pemboleh ubah & \multicolumn{2}{c}{ Tahap } & \multicolumn{2}{c}{ Tahap } & \multicolumn{2}{c}{ Tahap } & Min & SP & Tahap Purata \\
& Rendah & \multicolumn{2}{c}{ Sederhana } & \multicolumn{2}{c}{ Tinggi } & & & \\
& $\mathbf{N}$ & $\mathbf{\%}$ & $\mathbf{N}$ & $\mathbf{\%}$ & $\mathbf{N}$ & $\boldsymbol{\%}$ & & & \\
\hline $\begin{array}{l}\text { Penggunaan } \\
\text { Barangan Elektrik }\end{array}$ & 9 & 2.3 & 390 & 97.5 & 1 & 0.3 & 1.98 & 0.15 & Sederhana \\
\hline
\end{tabular}

Jadual 4 - Perbezaan pemboleh ubah pendapatan dengan penggunaan barangan.

\begin{tabular}{llccccc}
\hline Pemboleh ubah & Punca Variasi & JKD & dk & MKD & F & p \\
\hline Pendapatan & Antara Kumpulan & 192.438 & 31 & 6.209 & 10.311 & .000 \\
& Dalam Kumpulan & 221.560 & 368 & .602 & & \\
& Jumlah & 413.998 & 399 & & & \\
\hline
\end{tabular}

*Signifikan pada $\mathrm{p}<0.05$

Seterusnya dalam meneliti hubungan antara pemboleh ubah penggunaan barangan elektrik dan amalan penjimatan tenaga elektrik isi rumah (Jadual 6) menunjukkan terdapat hubungan signifikan yang negatif dan lemah di antara penggunaan pendingin hawa dengan amalan penjimatan tenaga elektrik $(r=-0.124, p=0.01) p<0.05$. Seterusnya, bagi penggunaan televisyen/ pembesar suara/ radio, turut menunjukkan hubungan signifikan yang negatif dan lemah dengan amalan penjimatan tenaga elektrik $(r=-0.251, p=0.00) \mathrm{p}<0.01$. Bagi penggunaan mesin basuh pula turut menunjukkan hubungan signifikan yang negatif dan lemah dengan amalan penjimatan tenaga elektrik $(r=-0.251, p=0.00) p<0.01$. Penggunaan peti sejuk turut menunjukkan hubungan signifikan yang negatif dan lemah dengan amalan penjimatan elektrik $(r=-0.116, p=0.02) p<0.05$. Penggunaan lampu turut menunjukkan hubungan signifikan yang negatif dan lemah dengan amalan penjimtan tenaga elektrik $(\mathrm{r}=-1.46, \mathrm{p}=0.003) \mathrm{p}<0.01$. Penggunaan periuk nasi turut menunjukkan hubungan signifikan yang negatif dan lemah dengan amalan penjimatan elektrik $(r=-0.117, p=0.019)$ $\mathrm{p}<0.05$. Namun begitu, bagi penggunaan barangan elektrik secara keseluruhan, penggunaan kipas meja, kipas siling, cerek, ketuhar, mesin air elektrik, alat pemanas mandian, komputer/komputer riba/notebook tidak menunjukkan sebarang hubungan yang signifikan terhadap amalan penjimatan elektrik. 
Jadual 5 - Keputusan korelasi sub pemboleh ubah penggunaan barangan elektrik.

\begin{tabular}{lcc}
\hline \multicolumn{1}{c}{ Pemboleh Ubah } & \multicolumn{2}{c}{ Amalan Penjimatan Tenaga Elektrik Keseluruhan } \\
\cline { 2 - 3 } & $r$ & $\mathrm{p}$ \\
\hline Penggunaan Barangan elektrik Keseluruhan & -0.094 & 0.06 \\
Pendingin Hawa & $-0.124^{*}$ & 0.01 \\
Televisyen/Pembesar Suara/ Radio & $-0.251^{* *}$ & 0.00 \\
Mesin Basuh & $-0.246^{* *}$ & 0.00 \\
Kipas Meja & 0.019 & 0.70 \\
Kipas Siling & -0.015 & 0.77 \\
Peti Sejuk & $-0.116^{*}$ & 0.02 \\
Lampu & $-0.146^{* *}$ & 0.003 \\
Cerek & 0.051 & 0.31 \\
Ketuhar & -0.017 & 0.73 \\
Periuk Nasi & $-0.117^{*}$ & 0.019 \\
Mesin Air Elektrik & -0.004 & 0.935 \\
Alat Pemanas Mandian & -0.030 & 0.55 \\
Komputer & -0.056 & 0.265 \\
Mesin Cetak & 0.063 & 0.205 \\
\hline
\end{tabular}

$* *$ signifikan pada $\mathrm{p}<0.01$.

* signifikan pada $\mathrm{p}<0.05$

Melalui dapatan kajian daripada penggunaan pendingin hawa yang menunjukkan bahawa hubungan yang negatif dan lemah dengan amalan penjimatan tenaga elektrik $(r=-0.124, p=0.01)$. Keadaan ini bermaksud penggunaan pendingin hawa yang tinggi menunjukkan bahawa isi rumah mempunyai kesedaran penjimatan tenaga elektrik walaupun berlaku sedikit pembaziran. Kenyataan ini disokong oleh kajian Lundgren dan Kjellstrom (2013) yang menyatakan bahawa penggunaan pendingin hawa tinggi adalah disebabkan peningkatan pendapatan dan ia turut menjadi satu keperluan untuk melindungi isi rumah daripada pendedahan haba panas yang tinggi. Begitu juga kajian yang dilakukan oleh McClaren, (2015) yang mengatakan bahawa isi rumah yang mempunyai pendapatan yang tinggi cenderung untuk menggunakan barangan elektrik dengan tidak cermat dan mempunyai kesedaran terhadap label "ENERGY STAR” namun masih berlaku pembaziran yang berlaku dalam kalangan isi rumah.

\section{Kesimpulan}

Kelestarian alam adalah penting bagi memastikan kehidupan seharian manusia tidak dan ekosistem yang lebih terjamin pada masa akan datang. Amalan rendah karbon penting untuk memastikan kesejahteraan hidup masyarakat yang lebih holistik. Penjimatan tenaga elektrik yang digunakan secara cekap, efisien dan optimum adalah langkah terbaik bagi mengurangkan penghasilan gas rumah hijau iaitu gas karbon dioksida secara berlebihan ke ruangan atmosfera.

Pelan Induk Kecekepan Tenaga Nasional (NEEM) telah dibangunkan dalam Rancangan Malaysia Ke-10 (RMK10) iaitu dari tahun 2011 hingga 2015 memberi panduan dan halatuju penggunaan tenaga dengan cekap, khususnya penggunaan barangan elektrik. Selain bertujuan untuk menggalakkan penjimatan tenaga, pelan ini juga turut berperanan untuk menggalakkan pertumbuhan pembangunan produk dan reka bentuk bangunan yang menggunakan tenaga secara efisien. Pelan yang merupakan strategi serampang dua mata ini diharapkan dapat menjimatkan kos tenaga menerusi penjimatan tenaga dan menggunakan tenaga dengan lebih cekap dan seterusnya dapat membantu Malaysia dalam mengurangkan sehingga $40 \%$ pelepasan karbon menjelang tahun 2020. Dalam pengurusan tenaga, selain aspek penggunaan peralatan elektrik yang dapat menjimatkan tenaga, para pengguna juga harus diberikan pengetahuan dalam menggunakan tenaga yang cekap. Dengan kata lain, pengguna harus diberikan kesedaran tentang betapa pentingnya penggunaan tenaga secara cekap dan dapat menyelamatkan alam sekitar serta menjimatkan kos. Ini bermakna, masyarakat perlu mengubah gaya hidup mereka kepada kehidupan yang lebih mesra alam agar kelestarian alam sekitar dapat dikekalkan. Kesedaran dan amalan seharusnya diseimbangkan agar dapat memastikan semua pihak yang terlibat mampu melaksanakan tanggungjawabnya tanpa menuding jari kepada pihak yang lain.

\section{Rujukan}

Ahmad, F. A., Mohd Bakri I., Siti Nur Awanis M. Z., Rusamah A. J. (2015). E-waste management: An emerging global crisis and the Malaysian scenario. Journal of Environmental Sciences International, 4(4), 444-457. 
Andersson, D. (2016). Perspectives on low carbon lifestyles. Division of Physical Resource Theory. (Tesis PhD). Chalmers University of Technology, Sweden.

Bhattacharjee, S., Reichard, G., McCoy, A., Pearce, A., \& Beliveau, Y. (2014). Identification of elements to control and regulate residential energy consumption. Advances in Building Energy Research, 8(2), 174-195.

Broer, S. (2012). Solutions to climate change in UK housing developments: A lifestyle approach. (Tesis Sarjana). University College of London.

Brounen, D., Kok, N., \& Quigley, J. M. (2012). Residential energy use and conservation: Economics and demographics. European Economic Review, 56(5), 931-945.

Engku Siti Zaharah, E. A., Aziz, A. A., \& Mustapha, N. H. N. (2013). Potensi penjimatan penggunaan tenaga oleh isi rumah di Malaysia. Prosiding Persidangan Kebangsaan Ekonomi Malaysia Ke VIII 2013 2, 1004-1010.

Fauziah, I. (2011). Tahap kesedaran pelajar UPSI: Di Kolej Kediaman dan luar kolej terhadap amalan penjimatan tenaga elektrik di tempat kediaman. (Tesis Ijazah Sarjana Muda). Universiti Pendidikan Sultan Idris, Perak.

Fithri, P., Susanti, L., \& Bestarina, K. (2014). Assessing household energy savings and consumer behavior in Padang City. Proceedings of the International Multi Conference of Engineers and Computer Scientists, 12-14 March, 2014, Hong Kong.

Frederiks, E. R., Stenner K., Hobman E. V. (2015). Household energy use: Applying behavioural economics to understand consumer decision-making and behaviour. Renewable and Sustainable Energy Reviews, 41, 1385 - 1394.

Gaidajis, G., Angelakoglou, K., \& Aktsoglou D. (2010). E-waste: environment problems and current management. Journal of engineering Science and Technology Review, 3(1), 193-199.

Heinonen, J., \& Junnila, S. (2014). Residential energy consumption patterns and the overall housing energy requirements of urban and rural households in Finland. Energy and Buildings, 76, 295-303

Hori, S., Kondo, K., Nogata, D., \& Ben, H. (2013). The determinants of household energy-saving behavior: Survey and comparison in five major Asian cities. Energy Policy, 52, 354-362.

Jamilah, A., Shuhaida, M. N., \& Nurzali, I. (2015). Investigating students' environmental knowledge, attitude, practice and communication. Asian Social Science, 11(16), 284-293.

Jenni, Y. M., Poikela, K., Lehtinen, U., Keiski, R., Pongracz, E. (2014). Implementation of waste electrical and electronic equipment directive in Finland: evaluation of the collection network and challenges of the effective WEE management. Resources, Conservation \& Recycling, 86, 38-46.

Jones, R. V., Fuertes, A., \& Lomas, K. J. (2015). The socio-economic, dwelling and appliance related factors affecting electricity consumption in domestic buildings. Renewable and Sustainable Energy Reviews, 43, 901-917.

Jones, R. V., \& Lomas, K. J. (2016). Determinants of high electrical energy demand in UK homes: Appliance ownership and use. Energy and Buildings, 117, 71-82.

Khandakar M. H. A. R. (2016). Resourceful recycling process of waste desktop computers: A review study. Resources, Conservation and Recycling, 110, 30-47.

Kavousian, A., Rajagopal, R., \& Fischer, M. (2013). Determinants of residential electricity consumption: Using smart meter data to examine the effect of climate, building characteristics, appliance stock, and occupants' behavior. Energy, $55,184-194$.

Kleebrang, W, Bunditsakulchai, P. \& Wangjiraniran W. (2015). Household electricity demand forecast and energy savings potential for Vientiane, Lao PDR. International Journal of Sustainable Energy, 36, 344-367.

Lillemo, S. C. (2014). Measuring the effect of procrastination and environmental awareness on households' energysaving behaviours: An empirical approach. Energy Policy, 66, 249-256. 
Lundgren, K., \& Kjellstrom, T. (2013). Sustainability challenges from climate change and air conditioning use in urban areas. Sustainability (Switzerland), 5, 3116-3128.

McClaren, M. S. (2015). Energy efficiency and conservation attitudes: An exploration of a landscape of choices. (Tesis $\mathrm{PhD})$, Portland State University, Oregon.

Mulugetta, Y., \& Urban, F. (2010). Deliberating on low carbon development. Energy Policy, 38, 7546-7549.

Najmi, A., G., H. S., \& Keramati, A. (2014). Energy consumption in the residential sector: a study on critical factors. International Journal of Sustainable Energy, 35, 645-663.

Naz Arif \& Rafia Afroz. (2014). Electrical and electronic waste management-A Case study in University of Duhok, Iraq. Journal of Economics and Sustainable Development, 5(1), 21-27.

Nur Sumaiyyah, S., Gautam, L. S. \& Mohd Badruddin M. Y. (2015). Current Waste generation of e-waste and challanges in developing countries: An overview. Malaysian Journal of Civil Engineering, 27(1), 110-120.

Pachauri, R. K., Allen, M. R., Barros, V. R, Broome, J., Cramer, W. Christ, R. \& Dubash, N. K.( 2014). Climate Change 2014: Synthesis Report. Contribution of Working Group I, II, III to The Fifth Assessment Report of The Intergovernment Panel on Climate Change.

Pang, J., Chen, X., Zhang, Z., \& Li, H. (2016). Measuring eco-efficiency of agriculture in China. Sustainability (Switzerland), 8, 1- 15 .

Parameshwari, A. M. K. (2016). Factors Influencing energy consumption among moderately low income residents in multifamily rental apartments. (Tesis Sarjana). Georgia Institute of Technology, Georgia.

Pérez-belis, V., Bovea M. D., Simó A. (2014). Consumer behaviour and environmental education in the field of waste electrical and electronic toys: A Spanish case study. Waste Management, 36, 277-288.

Rafia Afroz, Muhammad Mehedi, M., Rulia Akhtar \& Jarita, D. (2013). Public environment awareness and performance in Kuala Lumpur city, Malayasia: A case study on household electrical and electronic equipment. Environment and Urbanization ASIA, 3(2), 385-396.

Simson. J. J. (2012). Study on sustainable Low Carbon Society in Malaysian regional development. (Tesis PhD). Japan: Kyoto University.

Siti Khatijah, Z., \& Christopher, P. (2016). Cabaran dan strategi ke arah pembentukan komuniti lestari. Malaysia Journal of Society and Space, 12(12), 10-24.

Tan, P. S., \& Azman, N. (2011). Hubungan antara komitmen terhadap alam sekitar dengan tingkah laku mesra alam sekitar dalam kalangan pelajar universiti. Jurnal Pesonalia Pelajar, 1(14), 11-22.

Tso, G. \& Guan, J. (2014). A multilevel regression approach to understand effects of environment indicators and household features on residential energy consumption. Energy, 66, 722-731

Vassileva I. (2012). Characterization of household energy consumption in Sweden: energy savings potential and feedback approaches. (Tesis $\mathrm{PhD})$. Mälardalen University, Sweden.

Wu, G., Liu, T., \& Tang, M. (2012). Analysis of household energy consumption and related $\mathrm{CO}_{2}$ emissions in the disregarded villages of Lijiang City, China. International Journal of Sustainable Development \& World Ecology, 19(6), 500-505.

Yohanis, Y., G., (2012). Domestic energy use and householders' energy behavior. Energy Policy, 41, 654 - 665.

Yuan, H., Zhou, P., \& Zhou, D. (2011). What is low-carbon development? A conceptual analysis. Energy Procedia, 5, 1706-1712.

Zainal, M., Z., Kamarudin, N., \& Azlizan T. (2014). Sustainable urban community development through Agenda 21. Journal of Techno Social, 6(1), 1-10 
Zareie B., Nima J. N. (2016). Computers in human behavior the impact of electronic environmental knowledge on the environmental behaviors of people. Computers in Human Behavior, 59, 1 -8.

Zhang, H. (2013). Household energy consumption in China 1987-2007. (Tesis PhD). Rutgers University, New Jersey.

Zhou, K., \& Yang, S. (2016). Understanding household energy consumption behavior: The contribution of energy big data analytics. Renewable and Sustainable Energy Reviews, 56, 810-819. 